\title{
Wakaf sebagai Instrumen Ekonomi Pembangunan Islam
}

\author{
Nasrul Fahmi Zaki Fuadi \\ Universitas Islam Negeri Walisongo Semarang \\ email: zaki.fuadi@walisongo.ac.id
}

\begin{abstract}
This study aimed to analyze the role of waqf as an economic instrument for Islamic development. This was motivated by unresolved poverty conditions. That poor people still experience difficulties in meeting their primary needs. On the other hand, endowments as Islamic economic instruments have excellent potential in developing the economy and providing benefits to the community. This study uses qualitative methods by reviewing kinds of literature in obtaining waqf models in several countries and their success. The results show that endowments have potential in economic development. Some countries show their success in managing waqf and providing benefits to the community. The results of this study also show that Indonesia has a very good waqf potential and is able to be a solution to the problem of poverty.
\end{abstract}

Keywords: Waqf; Islamic Economic Development; Islamic Economic.

\begin{abstract}
Abstrak: Artikel ini mencoba untuk menganalisis bagaimana peran wakaf sebagai intrumen ekonomi pembangunan Islam. Hal tersebut dilatarbelakangi oleh kondisi kemiskinan yang belum terselesaikan. Bahwa penduduk miskin masih mengalami kesulitan dalam memenuhi kebutuhan primernya. Di sisi lain, wakaf sebagai intrumen ekonomi Islam memiliki potensi yang sangat baik dalam pengembangan perekonomian dan memberikan manfaat bagi masyarakat. Penelitian ini menggunakan metode kualitatif dengan mengkaji beberapa sumber dalam mendapatkan model wakaf di beberapa negara dan keberhasilannya. Hasil penelitian menunjukkan bahwa wakaf memiliki potensi dalam pembangunan ekonomi. Beberapa negara menunjukkan keberhasilannya dalam mengelola wakaf dan memberikan manfaat bagi masyarakat. Hasil dari penelitian ini juga menunjukkan bahwa Indonesia memiliki potensi wakaf yang sangat baik dan mampu menjadi solusi dari masalah kemiskinan.
\end{abstract}

Kata Kunci: Wakaf; Ekonomi Pembangunan Islam; Ekonomi Islam.

Economica: Jurnal Ekonomi Islam - Volume 9, Nomor 1 (2018) 


\section{Pendahuluan}

Wakaf merupakan salah satu sumber dana yang memiliki potensi dalam pengembangan ekonomi umat (Munir 2013). Selain wakaf juga terdapat sumber dana sosial lain seperti zakat, infak, dan sedekah. Umat Islam di Indonesia telah lama mengenal dan menerapkan wakaf, yaitu sejak agama Islam masuk ke Indonesia. Wakaf sangat erat hubungannya dengan kegiatan sosial seperti halnya kegiatan sosial yang lain. Bahkan wakaf bisa dijadikan sebagai dana abadi umat yang memberikan manfaat dalam mensejahterakan masyarakat (Medias 2017). Hal ini jika dikaitkan dengan jumlah penduduk umat muslim di Indonesia tentu akan sangat tepat. Indonesia adalah negara dengan jumlah penduduk beragama Islam terbesar.

Menurut hasil sensus penduduk tahun 2010 (Na'im and Syaputra 2011) Indonesia adalah negara dengan mayoritas penduduk beragama Islam (87.18\%). Religiusitas Muslim di Indonesia juga cukup baik, terbukti dengan banyaknya umat Islam yang menunaikan ibadah haji di setiap tahunnya dan maraknya ibadah umrah. Jumlah Muslim dan religiusitas masyarakat tersebut seharusnya memberikan korelasi dan efek positif terhadap persoalan wakaf di Indonesia.

Tabel 1. Jumlah Penduduk Berdasarkan Agama yang Dianut

\begin{tabular}{lrr}
\hline \multicolumn{1}{c}{ Agama } & Jumlah Pemeluk (jiwa) & Persentase \\
\hline Islam & 207.176 .162 & 87,18 \\
Kristen & 16.528 .513 & 6,96 \\
Katolik & 6.907 .873 & 2,91 \\
Hindu & 4.012 .116 & 1,69 \\
Budha & 1.703 .254 & 0,72 \\
Khong hu cu & 117.091 & 0,05 \\
Lainnya & 299.617 & 0,13 \\
Tidak menjawab & 139.582 & 0,06 \\
Tidak ditanyakan & 757.118 & 0,32 \\
Jumlah & $\mathbf{2 3 7 . 6 4 1 . 3 2 6}$ & $\mathbf{1 0 0}$ \\
\hline
\end{tabular}

Sumber: Hasil Sensus Penduduk Tahun 2010 
Keberhasilan negara-negara Muslim adalah bukti bahwa wakaf mampu memberikan kontribusi dalam mengurai masalah perekonomian di sebuah negara. Mesir mampu membuktikan bahwa wakaf adalah salah satu sumber kesejahteraan masyarakat. Hal tersebut dikarenakan wakaf di Mesir dikelola dalam berbagai bidang; bidang properti, bidang pertanian dan reklamasi tanah, dan bidang ekonomi (Thayyeb 2012). Bahkan Amerika Serikat juga memiliki aset wakaf yang produktif, yaitu sebuah proyek apartemen senilai US\$85 juta di atas tanah yang dimiliki oleh the Islamic Cultural Center of New York (ICCNY). Wakaf di Amerika Serikat dikelola oleh Kuwait Awqaf Public Foundation (KAPF), yaitu sebuah lembaga keuangan Islam profesional. Wakaf dikelola secara profesional, sehingga hasil yang diperoleh pun juga maksimal (Medias 2017).

Keberhasilan beberapa negara, baik negara muslim maupun sekuler sekalipun, membuktikan bahwa wakaf memiliki potensi yang sangat baik untuk dikembangkan. Manfaat yang dihasilkan pun sedikit banyak memberikan kontribusi dalam mewujudkan kemandirian ekonomi umat. Dan wakaf tentunya dapat diperhitungkan sebagai instrumen ekonomi Islam dalam sebuah negara.

Potensi wakaf juga dimiliki oleh negara Indonesia. Pada tahun 2003 pusat penelitian CSRC UIN Syarif Hidayatullah Jakarta melakukan penelitian terkait dengan potensi wakaf produktif di Indonesia. Hasilnya bahwa tanah wakaf yang teridentifikasi seluas 154 ha oleh Kementerian Agama, yang dapat diperkirakan mempunyai nilai uang sekitar 590 triliun rupiah (Fuadi 2013).

Menurut data Direktorat Pemberdayaan Wakaf tahun 2011 dalam laporan Kepala Bidang Haji, Zakat, dan Wakaf Kantor Wilayah Kementerian Agama menyebutkan bahwa aset tanah wakaf di Indonesia mencapai 2.171.041.349,74 $\mathrm{m}^{2}$ atau sekitar $2171 \mathrm{~km}^{2}$ (Sutami 2012). Hal ini menunjukkan bahwa kesadaran masyarakat Muslim di Indonesia untuk berwakaf sudah baik. Luas tersebut sebanding dengan dua kali luas wilayah Jakarta. Aset wakaf tersebut jika dikelola dan dimanfaatkan lebih baik, 
utamanya yang memiliki nilai ekonomis tentunya akan memberikan output yang bermanfaat untuk umat. Manfaat yang dapat diperoleh dari wakaf dapat berupa bantuan pendidikan, pengentasan kemiskinan, penyediaan rumah murah bagi rakyat yang tidak mampu, dan juga bantuan kesehatan (Furqon 2016).

Pembangunan ekonomi merupakan pembangunan suatu negara dalam menciptakan kemakmuran ekonomi untuk kesejahteraan penduduknya (Huda 2015). Dalam upaya menciptakan kemakmuran ekonomi, ada indikator-indikator yang dapat digunakan, seperti; kemiskinan, ketimpangan, pengangguran, inflasi, dan pertumbuhan ekonomi. Kelima indikator tersebut dapat menunjukkan tingkat kesejahteraan masyarakat dalam menerima manfaat dari pembangunan ekonomi.

Badan Pusat Statistik (BPS) mendefinisikan penduduk miskin sebagai penduduk dengan pengeluaran per kapita per bulan di bawah garis kemiskinan. Dari gambar 1 terlihat bahwa pada bulan Maret 2018, jumlah penduduk miskin di Indonesia mencapai 25,95 juta orang atau $(9,82 \%)$. Jumlah tersebut mengalami penurunan sebesar 633,2 ribu orang dibandingkan dengan kondisi jumlah penduduk miskin pada September 2017 sebesar 26,58 juta orang (10,12\%). Meskipun pada bulan Maret 2018 angka kemiskinan di Indonesia menurun, namun hal ini tetap menjadi perhatian besar bagi pemerintah (Badan Pusat Statistik 2018).

Gambar 1. Jumlah dan Prosentase Penduduk Miskin, 1999 - Maret 2018

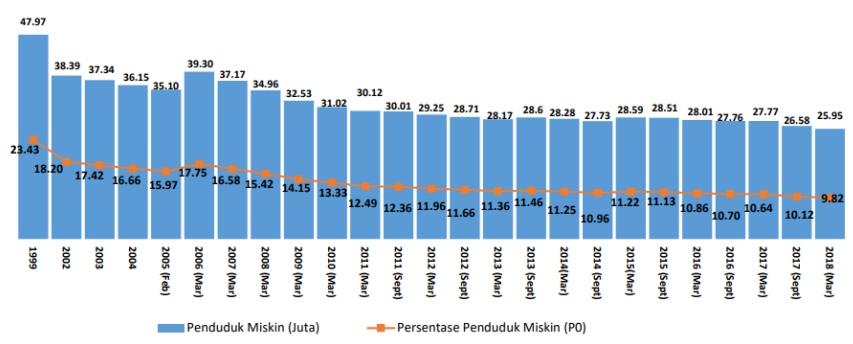

Sumber: Badan Pusat Statistik 2018 
Badan Pusat Statistik (BPS) menambahkan bahwa peranan komoditi makanan terhadap garis kemiskinan sangat signifikan. Jenis komoditi makanan memiliki tingkat paling tinggi dalam kebutuhan penduduk miskin, bahkan lebih besar dari kebutuhan perumahan, sandang, pendidikan, dan kesehatan. Pada tabel 2 menunjukkan bahwa sumbangan garis kemiskinan makanan sebesar 73,48\%. Angka ini mengalami kenaikan sebesar 73,35\% dibandingkan posisi September 2017 (Badan Pusat Statistik 2018). Kemampuan masyarakat miskin dalam mencukupi kebutuhan utama yaitu makanan menjadi hal yang krusial. Semua pihak harus memikirkan solusinya, tidak hanya pemerintah.

Tabel 2. Daftar Komoditi yang Memberi Sumbangan Besar terhadap Garis Kemiskinan beserta Kontribusinya (\%), Maret 2018

\begin{tabular}{lrlr}
\hline \multicolumn{1}{c}{ Jenis komoditi } & Perkotaan & Jenis komoditi & Perdesaan \\
\hline Makanan: & $\mathbf{7 1 , 0 4}$ & Makanan: & $\mathbf{7 6 , 6 6}$ \\
Beras & 20,95 & Beras & 26,79 \\
Rokok kretek filter & 11,07 & Rokok kretek filter & 10,21 \\
Telur ayam ras & 4,09 & Telur ayam ras & 3,28 \\
Daging ayam ras & 3,55 & Gula pasir & 3,07 \\
Mie instan & 2,43 & Mie instan & 2,21 \\
Gula pasir & 2,24 & Daging ayam ras & 2,08 \\
Kopi bubuk \& kopi & 1,88 & Kopi bubuk \& kopi & 1,93 \\
instan (sachet) & & instan (sachet) & \\
Kue basah & 1,78 & Bawang merah & 1,81 \\
Tempe & 1,74 & Roti & 1,80 \\
Tahu & 1,70 & Kue basah & 1,77 \\
Roti & 1,65 & Cabe rawit & 1,64 \\
Bawang merah & 1,50 & Tempe & 1,63 \\
Lainnya & 16,45 & Lainnya & 18,45 \\
Bukan Makanan: & $\mathbf{2 8 , 9 6}$ & Bukan Makanan: & $\mathbf{2 3 , 3 4}$ \\
Perumahan & 8,30 & Perumahan & 6,91 \\
Bensin & 4,36 & Bensin & 3,69 \\
Listrik & 3,89 & Listrik & 2,01 \\
Pendidikan & 1,99 & Pendidikan & 1,23 \\
Perlengkapan mandi & 1,30 & Perlengkapan mandi & 1,11 \\
& & & \\
\hline
\end{tabular}

Economica: Jurnal Ekonomi Islam - Volume 9, Nomor 1 (2018) 
Nasrul Fahmi Zaki Fuadi

\begin{tabular}{lclc}
\hline \multicolumn{1}{c}{ Jenis komoditi } & Perkotaan & \multicolumn{1}{c}{ Jenis komoditi } & Perdesaan \\
\hline Angkutan & 0,95 & Kayu bakar & 0,83 \\
Kesehatan & 0,85 & Kesehatan & 0,81 \\
Lainnya & 7,31 & Lainnya & 6,76 \\
\hline
\end{tabular}

Sumber: Badan Pusat Statistik 2018

Terdapat beberapa penelitian terdahulu yang membahas tentang peran wakaf dalam mensejahterakan masyarakat. Di antaranya adalah penelitian yang dilakukan oleh Medias (Medias 2017) yang membahas bagaimana bank wakaf mampu menjadi solusi dalam pemberdayaan sosial ekonomi Indonesia. Hasil penelitiannya menunjukkan bahwa wakaf uang memiliki potensi jika dikembangkan dengan cara yang optimal, yaitu dengan adanya bank wakaf tersebut. Sementara itu, penelitian yang dilakukan Bahri (Bahri 2016) membahas tentang peran wakaf produktif yang dilakukan oleh pemuda Muhammadiyah desa Longkeyang, Bodeh, Pemalang, dalam kesejahteraan masyarakat. Hasil dari penelitian ini menunjukkan pengaruh yang signifikan, bahwa wakaf produktif memberikan manfaat yang dapat dirasakan oleh masyarakat setempat. Penelitian lainnya dilakukan oleh Abdullah (Abdullah 2018) yang meneliti tentang bagaimana wakaf menjadi sebuah tujuan pembangunan berkelanjutan dengan pendekatan maqāṣid sharīah .

Setelah melihat potensi wakaf di Indonesia dan dengan melihat juga tingkat kemiskinan di Indonesia, maka penting untuk membahas lebih lanjut bagaimana wakaf dapat digunakan sebagai instrumen dalam pembangunan ekonomi, sehingga wakaf mampu membantu masyarakat miskin dalam mencukupi kebutuhan utamanya dan mengurangi angka kemiskinan di Indonesia.

\section{Definisi Wakaf dan Ruang Lingkup}

\section{Konsep Wakaf Klasik}

Wakaf secara umum dapat diartikan sebagai sebuah pemberian yang pelaksanaannya dilakukan dengan jalan menahan (pemilikan) asal (tạ̣biss al- 
așl), lalu menjadikan manfaatnya berlaku umum. Maksud dari menahan pemilikan asal (taḥbiss al-aṣl) adalah dengan menahan barang yang diwakafkan agar tidak di-tașarruf-kan (diwariskan, dijual, dihibahkan, digadaikan, disewakan dan sejenisnya). Adapun cara pemanfaatannya adalah dengan memanfaatkanya sesuai dengan kehendak pemberi wakaf (wakif) tanpa imbalan (Direktorat Pemberdayaan Wakaf 2007).

Wakaf memiliki dua fungsi yaitu sebagai ibadah kepada Allah dan juga berfungsi sosial sesama manusia. Fungsi wakaf sebagai ibadah dapat diartikan bahwa wakaf diharapkan menjadi bekal bagi kehidupan wakif (pemberi wakaf) di hari akhirat karena pahalanya akan terus menerus mengalir selama harta wakaf itu dimanfaatkan. Sedangkan wakaf dalam fungsi sosial dapat diartikan bahwa wakaf adalah aset yang memiliki peran dalam mempercepat pembangunan sebuah negara. Wakaf memiliki peran dalam pemerataan kesejahteraan di kalangan umat. Dan penanggulangan kemiskinan adalah salah satu sasaran dari manfaat wakaf.

\section{Dasar Hukum Wakaf}

\section{a. Al-Qur'an}

Dalam Al-Qur'an tidak ada ayat yang secara lugas menyebutkan atau mensyariatkan adanya wakaf secara umum maupun wakaf produktif secara khusus. Namun ada beberapa ayat yang memberi petunjuk dan sampai saat ini dapat dijadikan sebagai landasan hukum perwakafan baik wakaf langsung maupun wakaf produktif.

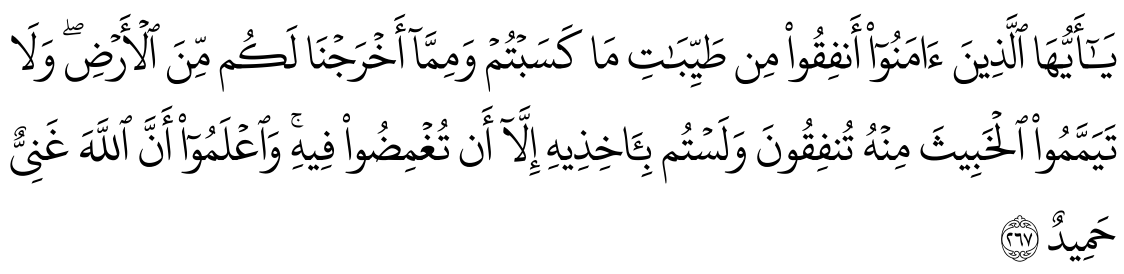

"Hai orang-orang yang beriman, nafkahkanlah (di jalan Allah) sebagian dari hasil usahamu yang baik-baik dan sebagian dari apa yang Kami

Economica: Jurnal Ekonomi Islam - Volume 9, Nomor 1 (2018) 
keluarkan dari bumi untukmu. Dan janganlah kalian memilih yang buruk-buruk lalu kalian menafkahkan daripadanya, padahal kalian sendiri tidak mau mengambilnya melainkan dengan memincingkan mata terhadapnya. Dan ketahuilah, bahwa Allah Maha Kaya lagi Maha Terpuji." (QS. al-Baqarah [2]: 267)

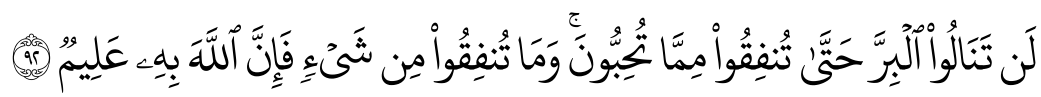

"Kalian sekali-kali tidak sampai kepada kebajikan (yang sempurna), sebelum kalian menafkahkan sebagian harta yang kalian cintai. Dan apa saja yang kalian nafkahkan maka sesungguhnya Allah mengetahuinya." (QS. Ali Imran [3]: 92)

Dalam dua ayat di atas, wakaf tidak disebutkan secara eksplisit. Kedua ayat tersebut menggunakan kata nafkah/menafkahkan (anfiqū/tunfiqū). Nafkah sendiri memiliki arti luas, biasanya diartikan sebagai sedekah. Dalam hal ini nafkah dalam ayat di atas dapat juga diartikan sebagai wakaf.

\section{b. Sunnah}

Sedangkan hadis-hadis yang dapat dijadikan landasan untuk perwakafan adalah sebagai berikut:

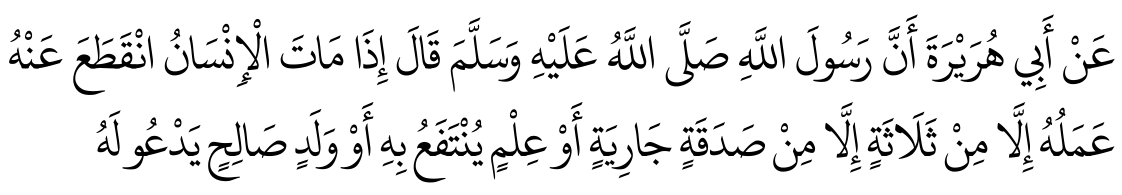

"Dari Abu Hurairah, bahwa Rasulullah saw bersabda: Apabila salah seorang manusia meninggal dunia, maka terputuslah segala amalannya kecuali tiga perkara; șadaqah jāriyah, ilmu yang bermanfaat baginya dan anak saleh yang selalu mendoakannya." (HR. Muslim)

Kebanyakan ulama menafsirkan șadaqah jāriyah dalam hadis tersebut sebagai pembahasan masalah wakaf (Lembaga Fatwa Mesir 2015). Karena antara sifat șadaqah jāriyah dengan sifat wakaf adalah dua hal yang serupa. Sehingga dapat dianalogikan bahwa wakaf adalah șadaqah jāriyah yang disebutkan dalam hadis tersebut. 
Selain hadis di atas yang secara tersirat dapat dijadikan sebagai rujukan dalil wakaf, yaitu hadis perintah Nabi kepada Umar bin Khattab untuk mewakafkan tanahnya yang ada di Khaibar. Hadis ini secara tegas dan jelas dapat kita jadikan pedoman atau dalil disyariatkannya wakaf (Direktorat Pemberdayaan Wakaf 2007).

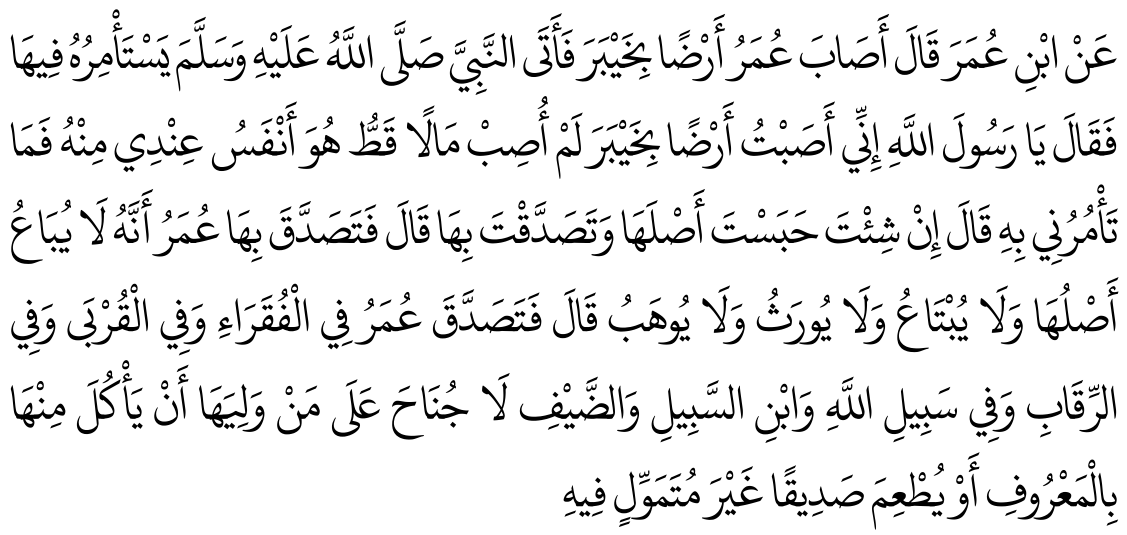

"Ibnu Umar berkata: Umar (bin Khattab) memperoleh sebidang tanah di Khaibar, lalu dia menemui Nabi saw untuk memohon petunjuk tentang tabah tersebut. Umar berkata: Wahai Rasulullah, saya memperoleh tanah di Khaibar, dan saya belum pernah mendapatkan harta yang sangat bernilai seperti kebun itu, maka apa yang engkau perintahkan kepadaku tentang tanah tersebut? Nabi menjawab: Jika kamu mau, engkau bisa menahan pokoknya dan menyedekahkanlah hasilnya. Ibnu Umar berkata: Kemudian Umar menyedekahkannya, pokoknya tidak dijual, tidak diwariskan dan tidak dihibahkan. Ibnu Umar melanjutkan: Umar menyedekahkan hasilnya kepada orang-orang fakir, karib kerabat, pemerdekaan budak, dana perjuangan di jalan Allah, untuk pejuangpejuang dan untuk menjamu tamu. Dan dia juga membolehkan orang lain untuk mengolah kebun tersebut dan memakan dari hasil tanamannya dengan sepantasnya, atau memberi makan temannya dengan tidak menyimpannya." (HR. Muslim).

Economica: Jurnal Ekonomi Islam - Volume 9, Nomor 1 (2018) 


\section{c. Peraturan Perundang-undangan}

Ada beberapa peraturan perundang-undangan yang mengatur masalah perwakafan di Indonesia, di antaranya adalah sebagai berikut (Direktorat Pemberdayaan Wakaf 2008):

1. Undang-Undang No. 41 Tahun 2004 tentang wakaf.

2. Undang-Undang Pokok Agraria.

3. Dalam Undang-Undang Pokok Agraria (UUPA) masalah wakaf dapat kita ketahui pada pasal 5, pasal 14 ayat 91 dan pasal 49.

4. Peraturan Pemerintah Nomor 42 Tahun 2006 tentang Pelaksanaan Undang-Undang Nomor 41 Tahun 2004 tentang wakaf.

5. Inpres No. 1 Tahun 1991 Tentang Kompilasi Hukum Islam (KHI)

Beberapa ketentuan hukum perwakafan menurut KHI yang merupakan pengembangan dan penyempurnaan terhadap materi perwakafan yang ada pada perundang-undangan sebelumnya, antara lain: objek wakaf, sumpah nazhir, jumlah nazhir, perubahan benda wakaf, pengawasan nazhir, peranan majelis ulama dan camat, pengawasan terhadap pelaksanaan tugas dan tanggung jawab nazhir dilakukan secara bersama-sama oleh kepala KUA kecamatan, MUI kecamatan dan Pengadilan Agama yang mewilayahinya (pasal 227) (Direktorat Pemberdayaan Wakaf 2008).

\section{Konsep Wakaf Produktif}

Dari wakaf yang umum ini terdapat macam-macam wakaf yang dikategorikan berdasarkan bentuk manajemennya, keadaan wakif, ekonomi, bentuk hukumnya, tujuannya, dan jenis barangnya. Sedangkan untuk macammacam wakaf berdasarkan sudut pandang ekonomi sendiri terbagi menjadi dua yaitu wakaf langsung dan wakaf produktif (Qahaf 2007).

1. Wakaf langsung adalah wakaf yang diberikan langsung kepada orangorang yang berhak. Contoh dari wakaf langsung adalah wakaf masjid, sekolah, rumah sakit, makam, dan lain sebagainya. Wakaf langsung ini 
manfaatnya dapat langsung dirasakan oleh masyarakat dan aset wakafnya dapat dijadikan modal tetap yang selalu bertambah di tiap tahunnya.

2. Wakaf produktif adalah harta atau benda benda yang diwakafkan untuk dipergunakan dalam kegiatan produksi yang menghasilkan, kemudian hasilnya dimanfaatkan sesuai dengan tujuan wakaf. Contoh dari wakaf produktif adalah wakaf tanah yang digunakan untuk bercocok tanam, mata air untuk dijual airnya, jalan dan jembatan untuk dimanfaatkan sebagai jasa penyeberangan dan ongkosnya diambil dari orang yang menggunakannya. Wakaf produktif dikelola dengan profesional sehingga menghasilkan keuntungan dan keuntungannya dapat dimanfaatkan sesuai dengan tujuan wakaf.

Perbedaan antara wakaf langsung dan wakaf produktif adalah terletak pada manajemen pengelolaan dan cara pelestarian wakaf tersebut. Wakaf langsung membutuhkan biaya perawatan yang dananya bersumber dari objek lain diluar benda wakaf. Hal ini dikarenakan wakaf langsung tidak menghasilkan sesuatu dan tidak boleh digunakan untuk tujuan tersebut. Sedangkan pada wakaf produktif, sebagian hasilnya dapat dipergunakan untuk perawatan dan pelestarian objek wakaf, dan selebihnya dapat dibagikan kepada orang-orang yang berhak sesuai dengan tujuan wakaf.

Yang termasuk dalam wakaf produktif diantaranya adalah wakaf uang. Wakaf uang adalah wakaf yang dilakukan seseorang, kelompok orang, lembaga atau badan hukum dalam bentuk uang tunai (Mardani 2015). Wakaf uang dikatakan lebih strategis dan bernilai produktif dibanding wakaf-wakaf lainnya. Hal ini dikarenakan uang sebagai alat beli/alat tukar dan modal lebih dibutuhkan masyarakat daripada barang-barang yang tidak bergerak seperti tanah (Karim and Sahroni 2015). Majelis Ulama Indonesia (MUI) telah mengeluarkan fatwa tentang wakaf tunai sebagai berikut: 
1. Wakaf uang (cash wakaf / waqfal-nuqud), adalah wakaf yang dilakukan oleh sekelompok atau seseorang maupun badan hukum yang berbentuk wakaf tunai.

2. Termasuk dalam pengertian uang adalah surat-surat berharga.

3. Wakaf yang hukumnya jawaz (boleh)

4. Wakaf yang hanya boleh disalurkan dan digunakan untuk hal-hal yang dibolehkan secara syar'i.

5. Nilai pokok wakaf yang harus dijamin kelestariannya, tidak boleh dijual, dihibahkan atau diwariskan.

Fatwa MUI tersebut kemudian diperkuat oleh hadirnya undang-undang No. 41 tahun 2004 tentang wakaf. Undang-undang tersebut menyebutkan bahwa wakaf tidak hanya benda tidak bergerak, tetapi juga dapat berupa benda bergerak, seperti uang. Dalam undang-undang tersebut juga diatur kebijakan perwakafan di Indonesia, mulai dari pembentukan nadzir sampai dengan pengelolaan harta wakaf (Medias 2010).

Lahirnya undang-undang no 41 tahun 2004 dapat dikatakan sebagai momentum titik balik dalam rangka pengembangan wakaf yang lebih luas. Wakaf tidak lagi pada benda/barang yang tidak bergerak, melainkan juga untuk benda/barang bergerak. Sehingga pengembangan wakaf menjadi lebih mudah dan bernilai produktif, tidak hanya berkisar pada kuburan dan tempat peribadatan. Tujuan dari wakaf untuk kemandirian dan kesejahteraan umat sangat mudah diperoleh. Bahkan dengan wakaf akan menjadikan pertumbuhan ekonomi Indonesia semakin baik.

\section{Ekonomi Pembangunan Islam}

Ekonomi pembangunan merupakan cabang ilmu ekonomi yang bersifat terapan, di mana ilmu ini lahir setelah terjadinya perang dunia kedua. Tujuan lahirnya ilmu ekonomi pembangunan adalah untuk mencari solusi dari berbagai permasalahan yang dihadapi oleh negara-negara yang baru merdeka. Di mana negara-negara tersebut sedang berkembang dan 
menghadapi berbagai masalah seperti kemiskinan, kebodohan, pengangguran, keterbelakangan, dan ketertinggalan dalam semua aspek kehidupan. Sementara itu, istilah pembangunan ekonomi biasanya dikaitkan dengan perkembangan ekonomi suatu negara (Almizan 2016).

Pembangunan ekonomi dan ekonomi pembangunan memiliki pengertian yang sama, keduanya sering kali digunakan beriringan dan saling bergantian, padahal keduanya memiliki arti dan orientasi yang berbeda. "Economic development is the development of economic wealth of countries or regions for the well-being of their inhabitants. The study of economic development is known as development economics". Kalimat tersebut dapat diartikan bahwa pembangunan ekonomi merupakan pembangunan kemakmuran ekonomi suatu negara untuk kesejahteraan penduduknya. Adapun studi tentang pembangunan ekonomi dikenal sebagai ekonomi pembangunan (Huda 2015).

Dalam perkembangannya, para ahli ekonomi mendefinisikan ekonomi pembangunan sebagai suatu studi yang ditujukan untuk meningkatkan taraf hidup penduduk di negara-negara yang sedang berkembang, dengan memecahkan masalah-masalah utamanya, yakni kemiskinan, pengangguran dan pemerataan (Aedy 2011). Menurut (Almizan 2016) pembangunan di negara-negara berkembang pada pelaksanaannya telah memunculkan pola, metode, atau model yang berbeda-beda di antara mereka.

Terdapat perbedaan antara sistem ekonomi sekuler dengan sistem ekonomi Islam. Sistem ekonomi sekuler didasarkan pada manusia ekonomi rasional, hukum pasar, dan positivisme. Sementara sistem ekonomi Islam didasarkan pada penyatuan antara yang lahir dan yang batin, antara dunia dan akhirat. Ekonomi Islam adalah sebuah cabang ilmu pengetahuan yang membantu merealisasikan kesejahteraan manusia melalui alokasi dan distribusi sumber daya langka yang sejalan dengan ajaran Islam dengan tanpa memberikan batasan individual atau menciptakan ketidakseimbangan makroekonomi dan ekologi secara berkelanjutan (Chapra 2001). Sementara 
itu, Mannan (Mannan 1993) mendefinisikan ilmu ekonomi Islam sebagai sebuah ilmu pengetahuan sosial yang mempelajari masalah-masalah ekonomi masyarakat yang diilhami oleh nilai-nilai Islam (Islamic economics is a social science which studies the economics problems of a people imbued with the values of Islam).

Untuk mengetahui sebuah sistem ekonomi Islam, kita dapat mengetahuinya melalui karakteristik dari ekonomi Islam, di antara karakteristik tersebut adalah sebagai berikut (Nasution et al. 2010):

1. Harta kepunyaan Allah dan manusia merupakan khalifah atas harta.

2. Ekonomi terikat dengan akidah, syariah (hukum), dan moral.

3. Keseimbangan antara kerohanian dan kebendaan.

4. Ekonomi Islam menciptakan keseimbangan antara kepentingan individu dengan kepentingan umum.

5. Kebebasan individu dijamin dalam Islam.

6. Negara diberi wewenang turut campur dalam perekonomian.

7. Bimbingan konsumsi.

8. Petunjuk investasi.

9. Zakat.

10. Larangan riba.

Pertumbuhan ekonomi dalam pandangan ekonomi Islam, tidak hanya hal-hal yang berkaitan dengan peningkatan barang dan jasa, melainkan juga dilihat dari aspek moralitas, kualitas akhlak serta keseimbangan antara tujuan duniawi dan ukhrawi (Almizan 2016). Seperti yang dinyatakan Ibnu Qayyim bahwa basis syariah dalam hal ini adalah hikmah dan kemaslahatan manusia di dunia dan akhirat. Kemaslahatan dimaksud meliputi beberapa aspek, di antaranya; keadilan, kebahagiaan, rahmat, dan kebijaksanaan. Apabila keadilan berubah menjadi penindasan, rahmat berubah menjadi kesulitan, kesejahteraan berubah menjadi kesengsaraan, dan hikmah berubah menjadi kebodohan, tidak ada hubungannya dengan syariah (Wasyith 2017). Mannan (Mannan 1993) menyatakan bahwa ekonomi pembangunan Islam tidak 
hanya berorientasi pada pembangunan fisik dan material saja, tetapi juga memerhatikan moral dan spiritual sumber daya manusianya. Pembangunan keimanan merupakan prakondisi yang diperlukan dalam ekonomi Islam. Hal ini dikarenakan keimanan merupakan pondasi bagi seluruh perilaku individu dan masyarakat (Iswandi 2013).

Menurut Fahim Khan strategi pembangunan ekonomi bertumpu pada strategi perluasan aktivitas wirausaha produktif, bukan bertumpu pada strategi perluasan lapangan kerja sektor formal (Murtadho 2017). Oleh karenanya, prinsip ekonomi Islam dalam pembangunan ekonomi tidak hanya dalam mencapai angka-angka pertumbuhan saja, melainkan lebih kepada manfaat yang didapatkan masyarakat baik yang sifatnya duniawi maupun ukhrawi. Bagaimana pertumbuhan ekonomi mampu meningkatkan tingkat religiusitas dari manusia, dan bagaimana pertumbuhan ekonomi memberikan maslahat kepada dunia dan seisinya. Namun sebaliknya, apabila ekonomi pembangunan menimbulkan kemudaratan seperti terjadinya keterbelakangan, kekacauan dan jauh dari nilai-nilai keadilan dan kemanusiaan, maka pertumbuhan ekonomi tersebut tidak sesuai dengan ekonomi Islam (Beik 2016).

\section{Potensi Wakaf untuk Ekonomi Pembangunan Islam}

\section{Keberhasilan Wakaf di Negara Lain}

Di Malaysia wakaf berkembang sejak tahun 2008, yaitu sebuah bangunan komersial dengan tinggi 34 tingkat yang dibangun di atas tanah seluas 52.838 $\mathrm{m}^{2}$. Bangunan ini dikenal dengan Menara Imara Wakaf yang menjadi salah satu ikon wakaf di Malaysia. Peruntukan bangunan tersebut untuk disewakan oleh Bank Islam Malaysia Berhad. Keuntungan dari sewa diperuntukkan kepada mustahik wakaf. Dan juga hotel-hotel di beberapa lokasi yang merupakan aset wakaf (Aula 2012).

Keberhasilan wakaf juga telah dirasakan oleh Turki, yaitu wakaf uang di Bursa sebuah kota di daerah Orhan Gazi. Pengembangan wakaf uang pada 
saat itu dikelola dengan cara bunga; yaitu dengan dipinjamkan kepada yang membutuhkan dan ditetapkan bunga ketika pengembaliannya. Sehingga praktik wakaf uang di Turki banyak menjadi perdebatan di kalangan masyarakat Muslim. Menurut Çizakça (Çizakça 1995) sekitar abad 18, sebanyak $10 \%$ dari penduduk Bursa yaitu 60.000 orang telah meminjam dana dari dana wakaf untuk keperluan mereka, baik pendidikan, kesehatan, keluarga, dan juga fasilitas-fasilitas umum. Hal tersebut menunjukkan bahwa wakaf uang di Turki memberikan efek yang positif terhadap kemakmuran masyarakat dan dapat membantu mencukupi kebutuhan masyarakat.

Wakaf di Mesir dikelola oleh Badan Wakaf Mesir yang berada di bawah Wizārah al-Awqāf (Kementerian Wakaf). Salah satu keberhasilan yang telah dicapai oleh Badan Wakaf Mesir adalah kontribusi harta wakaf dalam meningkatkan ekonomi masyarakat. Selain itu, Al-Azhar University di Cairo juga memiliki aset wakaf produktif, diantaranya adalah beberapa rumah sakit, pengelolaan wakaf Salah Kamil, pengelolaan al-Azhar Conference Center (AAC), pengelolaan gedung al-Azhar, dan juga pengelolaan hadiqah al-Azhar (Taman al-Azhar). Hasil dari pengelolaan wakaf al-Azhar dapat dirasakan langsung oleh mahasiswa berupa fasilitas sarana dan prasarana yang memadai, juga diberikan dalam kegiatan riset (penelitian) dan menyelesaikan studi secara gratis (Kasdi 2015). Keberhasilan tersebut dilatarbelakangi oleh penempatan wakaf, baik berupa benda tidak bergerak maupun benda bergerak, yang dikelola dengan cara profesional. Dana wakaf yang terkumpul diinvestasikan dalam bentuk saham dan obligasi pada bank-bank Islam dan perusahaan-perusahaan penting. Manfaat dari penempatan tersebut digunakan untuk mendirikan tempat-tempat ibadah, pendidikan, kesehatan, sosial, dan juga membantu kehidupan masyarakat (Mu’allim 2015).

Selain negara yang mayoritas Muslim, Singapura yang dikatakan negara sekuler pun menerapkan wakaf, bahkan dapat dikatakan sukses. The Strait Times dan The Business Time menyatakan bahwa praktik wakaf berasal dari Timur Tengah. Dan dibawa ke Singapura oleh pedagang Arab hampir 200 
tahun yang lalu. Pengelolaan dan pengembangan aset-aset wakaf yang telah dilakukan oleh Majelis Ugama Islam Singapura (MUIS) bersama Wakaf Real Estate Singapura (WAREES) dimana pengelolaan wakaf di Singapura cenderung dilakukan secara produktif (Suhairi 2015). Total keseluruhan asset wakaf di Singapura berjumlah $\$ 250$ juta. Wakaf di singapura beragam, baik masjid maupun hotel berbintang. Penghasilan bersih dari hotel tersebut mencapai S\$1.5 juta per tahun (Badan Wakaf Indonesia 2008). Keberhasilan manajemen wakaf di Singapura tidak hanya berkontribusi pada masyarakat sosial dan kebutuhan keagamaan di Singapura sendiri, bahkan manfaatnya dapat dirasakan oleh negara lain seperti India, Yaman, Arab Saudi, dan Indonesia (Koto and Saputra 2017).

\section{Potensi Wakaf di Indonesia}

Potensi tanah wakaf di Indonesia tergolong sangat besar. Hal ini dikarenakan jumlah penduduknya yang mayoritas adalah Muslim. Ahmed Mohamed Ali, Presiden Islamic Development Bank (IDB) menyatakan bahwa Badan Wakaf Indonesia (BWI) berpotensi menjadi pusat gerakan wakaf di kawasan Asia Tenggara. Terkait dengan itu, IDB menyarankan agar BWI mendirikan sebuah Bank Wakaf khusus untuk negara-negara di kawasan ASEAN (Sambas 2014).

Gambar 2. Penggunaan Tanah Wakaf

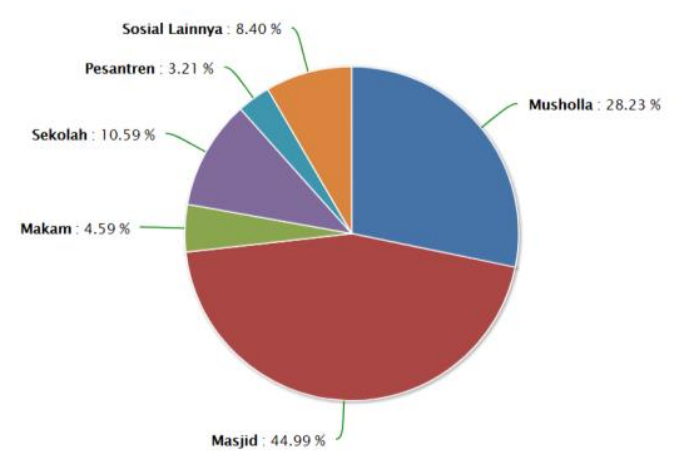

Sumber: Sistem Informasi Wakaf 2018

Economica: Jurnal Ekonomi Islam - Volume 9, Nomor 1 (2018)

http://journal.walisongo.ac.id/index.php/economica 
Indonesia dengan mayoritas penduduk Muslim memiliki potensi wakaf yang sangat besar. Berdasarkan data yang diperoleh dari Kementerian Agama Republik Indonesia, luas tanah wakaf di Indonesia sebesar 48.812,62 ha yang tersebar di 348.916 lokasi. Gambar 2 menjelaskan dari luas tanah wakaf tersebut, sebanyak 44,99\% digunakan untuk membangun masjid, 28,23\% untuk mushalla, 10,59\% sekolah, 8,40\% untuk sosial lainnya, 4,59\% untuk makam dan sisanya sebesar 3,21\% untuk pesantren (Direktorat Pemberdayaan Wakaf, n.d.).

Wakaf juga bisa digunakan sebagai suatu dana dalam meningkatkan infrastuktur untuk percepatan pembangunan, meningkatkan stuktur sosial di dalam proses pembangunan dengan berperan aktif dalam sektor kesehatan, pendidikan, investasi pelayanan publik serta mengambil alih anggaran investasi pemerintah sehingga memperkuat keuangan negara.

Dalam membantu mempercepat pembangunan infrastuktur, diperlukan wakaf tunai (wakaf uang) yang dikelola secara produktif. Wakaf uang tersebut sifatnya fleksibel sehingga lebih mudah untuk diterapkan ke hal-hal yang sifatya produktif seperti pembangunan jalan tol, membangun gedung ataupun lapangan sepakbola untuk disewakan, perbaikan di bidang pertanian dan perikanan ataupun rumah sakit milik pemerintahan. Dari proyek-proyek tersebut tentunya akan menghasilkan keuntungan yang sangat banyak apabila mampu dikekola dengan baik.

Jumlah umat muslim yang terbesar di dunia terutama di Indonesia merupakan sebuah aset besar dalam penghimpunan dan pengembangan wakaf uang. Jika wakaf uang dapat diimplementasikan dengan baik, maka akan terdapat dana potensial yang dapat dipergunakan bagi kemaslahatan umat.

Berdasarkan asumsi (Nafis 2011), jika 20 juta umat muslim di Indonesia bersedia mewakafkan uang senilai Rp100.000,00 setiap bulan, maka dana yang terkumpul berjumlah Rp24 triliun setiap tahun. Jika 50 juta orang yang 
berwakaf, maka setiap tahun akan terkumpul dana wakaf sebesar Rp60 triliun. Jika saja terdapat 1 juta umat Muslim yang mewakafkan dananya sebesar Rp100.000,00 per bulan, maka akan diperoleh pengumpulan dana wakaf sebesar Rp100 miliar setiap bulannya (Rp1,2 triliun per tahun).

Menurut Nasution (Nasution 2006), potensi wakaf di Indonesia dengan jumlah umat Muslim yang dermawan diperkirakan sebesar 10 juta jiwa dengan rata-rata penghasilan Rp500.000,00 hingga Rp10.000.000,00 maka paling tidak akan terkumpul dana sekitar 3 triliun per tahun dari dana wakaf seperti perhitungan dalam tabel 3:

Tabel 3. Potensi Wakaf Uang di Indonesia

\begin{tabular}{lllll}
\hline $\begin{array}{c}\text { Tingkat } \\
\text { penghasilan per } \\
\text { bulan }\end{array}$ & $\begin{array}{c}\text { Jumlah } \\
\text { Muslim }\end{array}$ & $\begin{array}{c}\text { Besar wakaf } \\
\text { per bulan }\end{array}$ & $\begin{array}{c}\text { Potensi wakaf } \\
\text { uang per } \\
\text { bulan }\end{array}$ & $\begin{array}{c}\text { Potensi wakaf } \\
\text { uang per tahun }\end{array}$ \\
\hline Rp500.000,00 & 4 juta & Rp5.000,00 & Rp20 miliar & Rp240 miliar \\
Rp1-2 juta & 3 juta & Rp10.000,00 & Rp30 miliar & Rp360 miliar \\
Rp2-5 juta & 2 juta & Rp50.000,00 & Rp100 miliar & Rp1,2 triliun \\
$>5$ juta & 1 juta & Rp100.000,00 & Rp100 miliar & Rp1.2 triliun \\
Total & & & & Rp3 triliun \\
\hline
\end{tabular}

Sumber: Makalah Nasution (Fuadi 2013)

Adapun penjelasan dari tabel 3 adalah sebagai berikut:

1. Apabila umat muslim yang berpenghasilan Rp500.000,00 sejumlah 4 juta orang dan setiap bulan masing-masing berwakaf sebanyak Rp5.000,00 maka setiap tahun terkumpul Rp240.000.000.000,00.

2. Apabila umat muslim yang berpenghasilan Rp1.000.000,00 Rp2.000.000,00 sejumlah 3 juta orang dan setiap bulan masing-masing berwakaf Rp10.000,00 maka setiap tahun terkumpul dana sebanyak Rp360.000.000.000,00.

3. Apabila umat muslim yang berpenghasilan Rp2.000.000,00 Rp5.000.000,00 sejumlah 2 juta orang dan setiap bulan masing-masing

Economica: Jurnal Ekonomi Islam - Volume 9, Nomor 1 (2018) 
berwakaf Rp50.000,00 maka setiap tahun terkumpul dana sebanyak Rp1.200.000.000.000,00.

4. Apabila umat muslim yang berpenghasilan Rp5.000.000,00 Rp10.000.000,00 sejumlah 1 juta orang dan setiap bulan masing-masing berwakaf Rp1.200.000,00 maka setiap tahun terkumpul dana sebanyak Rp1.200.000.000.000,00.

\section{Realita dan Tantangan}

Meskipun disebutkan bahwa potensi dari wakaf produktif dan wakaf uang di Indonesia sangat bagus, namun realitanya belum seperti yang diharapkan. Wakaf uang misalnya, dari potensi 3 triliun yang diharapkan akan terkumpul, namun realita yang ada hanya beberapa saja yang tercapai. Tercatat dalam laporan penerimaan wakaf uang dari Lembaga Keuangan Syariah Penerima Wakaf Uang (LKS-PWU) oleh BWI, saldo hingga 31 Desember 2012 sebesar Rp3.633.661.493. Artinya hanya 0,12\% dari asumsi potensi yang semestinya dicapai (lihat tabel 4 ).

Tabel 4. Rincian Penerimaan Wakaf Uang

\begin{tabular}{lrrrr}
\hline \multicolumn{1}{c}{ Nama LKS PWU } & \multicolumn{1}{c}{$\begin{array}{c}\text { Saldo Awal } \\
\text { Tahun 2011 }\end{array}$} & Peningkatan & $\begin{array}{r}\text { Saldo Akhir } \\
\text { Tahun 2012 }\end{array}$ & $\begin{array}{c}\text { Persentase } \\
\text { Kontribusi } \\
\text { (\%) }\end{array}$ \\
\hline Bank Muamalat Indonesia & $180,673,114$ & $182,200,000$ & $362,873,114$ & 32.18 \\
Bank Syariah Mandiri & $1,944,033,140$ & $281,352,755$ & $2,225,385,895$ & 49.68 \\
Bank BNI Syariah & $487,003,500$ & $8,206,434$ & $495,209,934$ & 1.45 \\
Bank DKI Syariah & $218,051,410$ & $53,714,000$ & $271,765,410$ & 9.49 \\
Bank Mega Syariah & $226,573,290$ & $7,409,300$ & $233,982,590$ & 1.31 \\
Bank Syariah Bukopin & $8,050,000$ & $18,451,450$ & $26,501,450$ & 3.26 \\
Bank BTN Syariah & $3,000,000$ & $14,943,100$ & $17,943,100$ & 2.64 \\
Total & $\mathbf{3 , 0 6 7 , 3 8 4 , 4 5 4}$ & $\mathbf{5 6 6 , 2 7 7 , 0 3 9}$ & $\mathbf{3 , 6 3 3 , 6 6 1 , 4 9 3}$ & $\mathbf{1 0 0}$ \\
\hline
\end{tabular}

Sumber: Laporan Tahunan Badan Wakaf Indonesia 2012 
Selain potensi yang dimiliki wakaf sangat besar dalam mendorong pertumbuhan ekonomi pembangunan, terdapat banyak tantangan yang perlu menjadi konsentrasi khusus dari beberapa pihak yang berkaitan. Beberapa tantangan dari wakaf dimaksud adalah sebagai berikut:

Pertama, minimnya jumlah nazir wakaf yang profesional di Indonesia. Hal ini menyebabkan tidak berkembangnya aset wakaf menjadi produktif. Utamanya yang terkait dengan wakaf uang. Selain itu, minimnya nazir yang sudah memiliki sertifikat dari Badan Wakaf Indonesia (BWI) untuk ditunjuk menjadi nazir. Bahkan di antara mereka yang belum memiliki sertifikat termasuk dalam nazir yang berpotensial. Dalam artian nazir sebuah instansi besar yang sudah memiliki aset wakaf produktif (Zamhari 2011).

Untuk mengelola dan mengembangkan wakaf produktif dengan baik dan benar, sangat diperlukan Sumber Daya Manusia (nazir) yang amanah, profesional, berwawasan ekonomi, tekun dan penuh komitmen yang kuat. Oleh karena itu, lembaga wakaf memiliki peran yang sangat strategis dalam terwujudnya wakaf produktif di Indonesia. Sosialisasi dan edukasi kepada nazir maupun masyarakat sangat dibutuhkan untuk tercapainya tujuan tersebut (Medias 2010).

Kedua, belum adanya proyek andalan dari lembaga wakaf dalam menjalankan wakaf produktif yang dihimpun dari masyarakat. Sehingga nazir maupun Lembaga Keuangan Syariah Penerima Wakaf Uang (LKS-PWU) mendapatkan kesulitan dalam menjelaskan kepada calon wakif tentang proyek yang akan didanai dari wakaf uang tersebut. Padahal dengan adanya proyek yang kongkrit ini, calon wakif akan yakin bahwa uang yang mereka wakafkan akan memberikan hasil yang maksimal dan terlihat manfaatnya untuk kepentingan umum (Zamhari 2011).

Ketiga, kurangnya sosialisasi wakaf produktif yang dilakukan pemerintah, lembaga wakaf, maupun kiyai kepada masyarakat. Masih banyak masyarakat yang belum memahami tentang konsep wakaf produktif. 
Pemahaman mereka akan wakaf masih pada wakaf yang tidak bergerak seperti tanah, kuburan, dan masjid. Sehingga ketika LKS-PWU memiliki produk wakaf uang, masyarakat masih bingung dan bertanya-tanya akan keabsahannya (Zamhari 2011). Fuadi menyebutkan dalam penelitiannya bahwa sosialisasi sangat memengaruhi minat nasabah bank syariah untuk berwakaf uang. Menurutnya, hal ini dikarenakan pengetahuan dan dorongan dari seseorang yang dianggap penting memberikan motivasi yang kuat terhadap seseorang untuk melakukan suatu aktivitas tertentu (Fuadi 2013).

Terkait dengan kurangnya sosialisasi, hal ini disebabkan oleh minimnya dana dari pemerintah maupun lembaga wakaf yang dialokasikan. Untuk melaksanakan sosialiasi tentu membutuhkan dana yang banyak. Dengan minimnya dana ini, pemerintah maupun lembaga wakaf kiranya dapat menambahkan alokasi dana sosialisasi kepada masyarakat (Syaukani 2012). Ditambahkan, menurut salah seorang nazir di BWI menyebutkan bahwa untuk melakukan sosialisasi di media-media modern saat ini juga membutuhkan dana yang tidak sedikit. Dan dana sosialisasi di BWI juga belum cukup untuk melakukan hal tersebut (Zamhari 2011).

\section{Simpulan}

Berdasarkan paparan di atas, dapat kita simpulkan bahwa negara-negara lain baik negara muslim maupun sekuler telah berhasil mengelola wakaf dengan profesional. Pengelolaan wakaf tersebut berdampak positif terhadap kemaslahatan masyarakatnya. Malaysia dengan Menara Imara Wakaf sebuah bangunan komersial untuk disewakan, Turki dengan wakaf uangnya, di mana masyarakat dapat meminjam uang dari dana tersebut, Mesir dengan wakafnya yang diinvestasikan dalam bentuk saham dan obligasi pada bankbank Islam dan perusahaan-perusahaan penting. Bahkan Amerika Serikat juga memiliki asset wakaf, yaitu sebuah proyek apartemen senilai US\$85 juta.

Indonesia dengan mayoritas penduduk Muslim tentunya memiliki potensi wakaf yang sangat besar jika dibandingkan dengan negara-negara di 
atas. Berdasarkan data yang diperoleh dari Kementerian Agama Republik Indonesia, luas tanah wakaf di Indonesia sebesar 47,263.36 ha. Bahkan potensi dari wakaf uang di Indonesia dengan jumlah umat Muslim yang dermawan diperkirakan sebesar 10 juta jiwa dengan rata-rata penghasilan Rp500.000,00 hingga Rp10.000.000,00 maka paling tidak akan terkumpul dana sekitar 3 triliun per tahun. Hal ini menunjukkan bahwa potensi wakaf di Indonesia sangat besar. Dan jika dimanfaatkan dan dikelola dengan baik, tentunya akan berdampak positif terhadap kemaslahatan masyarakat.

Pertumbuhan ekonomi suatu negara dapat dilihat salah satunya adalah dari indikator tingkat kemiskinan. Kemiskinan menjadi awal terjadinya kerusakan dan ketidakstabilan perekonomian negara. Data menunjukkan kemiskinan di Indonesia masih tergolong tinggi, meskipun data pada bulan Maret 2018 menunjukkan adanya penurunan jumlah masyarakat miskin jika dibandingkan dengan periode sebelumnya. Adapun jumlah penduduk miskin di Indonesia mencapai 25,95 juta orang atau (9,82\%). Kemampuan masyarakat miskin dalam mencukupi kebutuhan utama yaitu makanan menjadi hal yang krusial. Semua pihak harus memikirkan jalan keluarnya, tidak hanya pemerintah.

Ekonomi Islam hadir untuk memberikan solusi atas hal tersebut. Salah satu tujuan dari Ekonomi Islam adalah falāh, yaitu kemenangan di dunia dan akhirat. Salah satu instrumen dalam ekonomi Islam yang dapat dijadikan solusi adalah instrumen wakaf. Di mana wakaf memiliki nilai kekekalan dan manfaat yang bersifat umum. Tidak seperti instumen sosial lain dalam Ekonomi Islam yang bersifat konsumtif, seperti zakat, infak, dan sadaqah. Pengelolaan wakaf yang profesional menjadi realita dan tantangan Indonesia. Dukungan penuh dari pemerintah juga menjadi hal terpenting dalam kesuksesan pengelolaan wakaf, misalnya dalam penempatan dana wakaf pada pembangunan infrastruktur. Tentunya dukungan semua pihak juga diharapkan, termasuk akademisi dan juga tokoh masyarakat dalam mensosialisasikan wakaf kepada masyarakat awam

Economica: Jurnal Ekonomi Islam - Volume 9, Nomor 1 (2018) 


\section{Daftar Pustaka}

Abdullah, Mohammad. 2018. "Waqf, Sustainable Development Goals (SDGs) and Maqasid Al-Shariah." International Journal of Social Economics 45 (1). Emerald Publishing Limited: 158-72. https://doi.org/10.1108/IJSE-102016-0295.

Aedy, Hasan. 2011. Teori Dan Aplikasi Ekonomi Pembangunan PerspektifIslam, Sebuah Studi Komparasi. Yogyakarta: Graha Ilmu.

Almizan. 2016. "Pembangunan Ekonomi Dalam Perspektif Ekonomi Islam." Maqdis: Jurnal Kajian Ekonomi Islam 1 (2): 203-22.

Aula, Muhammad Abbas. 2012. "Pemberdayaan Umat Melalui Lembaga Wakaf." Al-Awqaf: Jurnal Wakaf Dan Ekonomi Islam 7 (2): 66-77.

Badan Pusat Statistik. 2018. "Profil Kemiskinan Di Indonesia Maret 2018." Jakarta.

Badan Wakaf Indonesia. 2008. "Belajar Mengelola Wakaf Dari Negeri Singa." 2008. https://bwi.or.id/index.php/asdfsdaf/1-beritawakaf/94-belajarmengelola-wakaf-dari-negeri-singa.html.

Bahri, Amirul. 2016. "Peranan Wakaf Produktif Pemuda Muhammadiyah Untuk Kesejahteraan Warga Desa Longkeyang, Bodeh, Pemalang." Indonesian Journal of Islamic Literature and Muslim Society 1 (2): 199. https://doi.org/10.22515/islimus.v1i2.499.

Beik, Irfan Syauqi. 2016. Ekonomi Pembangunan Syariah. Jakarta: Raja Grafindo Persada.

Chapra, M. Umer. 2001. Masa Depan Ilmu Ekonomi: Sebuah Tinjauan Islam. Jakarta: Gema Insani Press.

Çizakça, Murat. 1995. "Cash Waqfs of Bursa, 1555-1823." Journal of the Economic and Social History of the Orient 38 (3). Brill: 313-54. https://doi.org/10.2307/3632481.

Direktorat Pemberdayaan Wakaf, Departemen Agama Republik Indonesia. n.d. Jumlah Tanah Wakaf Seluruh Indonesia. Direktorat Jenderal Bimbingan Masyarakat Islam.

- — . 2007. Paradigma Baru Wakaf Di Indonesia. Jakarta: Direktorat Jenderal Bimbingan Masyarakat Islam. 
- - 2 2008. Panduan Pemberdayaan Tanah Wakaf Produktif Strategis Di Indonesia. Jakarta: Direktorat Jenderal Bimbingan Masyarakat Islam.

Fuadi, Nasrul Fahmi Zaki. 2013. "Intensi Nasabah Bank Syariah Untuk Berwakaf Uang Di Badan Wakaf Indonesia (BWI): Studi Kasus Pada Bank Syariah Mandiri Jakarta Pusat." Universitas Indonesia.

Furqon, Ahmad. 2016. "Model-Model Pembiayaan Wakaf Tanah Produktif." Economica: Jurnal Ekonomi Islam 5 (1): 1. https://doi.org/10.21580/ economica.2014.5.1.760.

Huda, Nurul. 2015. Ekonomi Pembangunan Islam. 1st ed. Jakarta: Kencana.

Iswandi, Lalu Muhammad. 2013. "Prinsip Dasar Pembangunan Dan Pertumbuhan Ekonomi Islam." Lisan Al-Hal: Jurnal Pengembangan Pemikiran Dan Kebudayaan 5 (2). Deighton, Bell, and Co: 363-82.

Karim, Adiwarman A, and Oni Sahroni. 2015. Maqashid Bisnis Dan Keuangan Islam: Sintesis Fikih Dan Ekonomi. Jakarta: Rajawali Pers.

Kasdi, Abdurrohman. 2015. Wakaf Produktif Untuk Pendidikan: Model Pengelolaan Wakaf Produktif Al-Azhar Asy-Syarif Cairo Mesir. Edited by Umma Farida. Yogyakarta: Idea Press.

Koto, Alaiddin, and Wali Saputra. 2017. "Wakaf Produktif Di Negara Sekuler: Kasus Singapura Dan Thailand." Sosial Budaya 13 (2): 116-39. https://doi.org/10.24014/SB.V13I2.3535.

Lembaga Fatwa Mesir. 2015. “فتاوى بحثية - الفرق بين الوقف والصدقة الجارية." 2015.

Mannan, Muhammad Abdul. 1993. Ekonomi Islam: Teori Dan Praktek. Yogyakarta: Dana Bhakti Wakaf.

Mardani, Dr. 2015. Aspek Hukum Lembaga Keuangan Syariah Di Indonesia. Jakarta: Kencana.

Medias, Fahmi. 2010. "Wakaf Produktif Dalam Perspektif Ekonomi Islam." La_Riba 4 (1): 71-86. https://doi.org/10.20885/lariba.vol4.iss1.art5.

—_- 2017. "Bank Wakaf: Solusi Pemberdayaan Sosial Ekonomi Indonesia." Indonesian Journal of Islamic Literature and Muslim Society 2 (1): 61-84. https://doi.org/10.22515/islimus.v2i1.749.

Mu'allim, Amir. 2015. "Pengaruh Pengelolaan Wakaf Di Mesir Terhadap Pengelolaan Harta Wakaf Pendidikan Di Indonesia (Studi Terhadap Ijtihad Dalam Pengelolaan Wakaf Pendidikan Di UII Dan Pondok Modern 
Gontor)." Akademika: Jurnal Pemikiran Islam 20 (1). Institut Agama Islam Negeri Metro: 103-22.

Munir, Zainal Arifin. 2013. "Revitalisasi Manajemen Wakaf Sebagai Penggerak Ekonomi Masyarakat." Journal de Jure 5 (2). https://doi.org/10.18860/jfsh.v5i2.3007.

Murtadho, Ali. 2017. "Strategi Pembangunan Ekonomi Yang Islami Menurut Fahim Khan." Economica: Jurnal Ekonomi Islam 7 (2): 1. https://doi.org/10.21580/economica.2016.7.2.1153.

Na'im, Akhsan, and Hendry Syaputra. 2011. Kewarganegaraan, Suku Bangsa, Agama Dan Bahasa Sehari-Hari Penduduk Indonesia Hasil Sensus Penduduk 2010. Edited by Sumarwanto and Tono Iriantono. Jakarta: Badan Pusat Statistik.

Nafis, M. Cholil. 2011. "Aplikasi Wakaf Uang Di Indonesia." Al-Awqaf: Jurnal Wakaf Dan Ekonomi Islam 4 (2): 37-50.

Nasution, Mustafa Edwin. 2006. Wakaf Tunai Inovasi Finansial Islam Peluang Dan Tantangan Dalam Mewujudkan Kesejahteraan Umat. Depok: PSTTIUI.

Nasution, Mustafa Edwin, Budi Setyanto, Nurul Huda, Muhammad Arief Mufraeni, and Bey Sapta Utama. 2010. Pengenalan Ekslusif Ekonomi Islam. 1st ed. Jakarta: Kencana.

Qahaf, Mundzir. 2007. Manajemen Wakaf Produktif. Jakarta Timur: Khalifa.

Sambas, Abas. 2014. "Perkembangan Pengelolaan Wakaf Di Indonesia: Potensi Dan Tantangan." Jurnal Bimas Islam 7 (4): 699-726.

Suhairi. 2015. "Implementasi Fungsi-Fungsi Manajemen Dalam Pengelolaan Wakaf Produktif Di Singapura." Akademika: Jurnal Pemikiran Islam 20 (1). Institut Agama Islam Negeri Metro: 123-36. http://ejournal.metrouniv.ac.id/index.php/akademika/article/view/437.

Sutami. 2012. "Perkembangan Wakaf Produktif Di Indonesia." Al-Awqaf: Jurnal Wakaf Dan Ekonomi Islam 7 (2): 13-21.

Syaukani, Imam. 2012. "Praktik Wakaf Pada Rumah Sakit Islam Sunan Kudus." Al-Awqaf: Jurnal Wakaf Dan Ekonomi Islam 5 (2): 22-43.

Thayyeb, Yuli Yasin. 2012. "Pengelolaan Wakaf Produktif Di Mesir." Al-Awqaf: Jurnal Wakaf Dan Ekonomi Islam 7 (2): 1-12. 
Wasyith. 2017. "Beyond Banking: Revitalisasi Maqāșid Dalam Perbankan Syariah." Economica: Jurnal Ekonomi Islam 8 (1): 1. https://doi.org/10.21580/economica.2017.8.1.1823.

Zamhari, Arif. 2011. "Implementasi Lembaga Keuangan Syariah Dalam Pengembangan Wakaf Uang Di Indonesia." Al-Awqaf: Jurnal Wakaf Dan Ekonomi Islam 4 (2): 51-60. 
